Piśmiennictwo zakonne $w$ dobie staropolskiej, red. Magdalena Kuran, Katarzyna KaczorScheitler i Michał Kuran, przy współpracy Dawida Szymczaka, Łódź 2013.

ANDRZEj WAŁKówsKi ${ }^{1}$

Uniwersytet Łódzki

\title{
Pochodzenie kancelaryjne dokumentów — sołtysa Piotra, Racibora Wojciechowicza oraz trzech przedstawicieli rodu Odrowązów dla klasztoru cystersów w Mogile z lat 1228-1231
}

W Krakowie na terenie Nowej Huty znajduje się klasztor cystersów. Jest on położony na ziemiach dawnej wsi Mogiły, która obecnie nie istnieje. Jednak nazwa tej wsi zachowała się i stanowi nadal tradycyjne określenie miejsca położenia opactwa: „Kraków Mogiła”. Klasztor ten jako jedyny obok Szczyrzyca utrzymał historyczną, nieprzerwaną ciaggłość i nie uległ kasacie w czasie zaborów3. Zachował przy tym swoje zasoby piśmiennictwa, do których należy klasztorne archiwum, zawierające liczne dokumenty, świadczące o szczególnej zapobiegliwości zakonników. Dokumenty te stanowiły bowiem zabezpieczenie podstaw ich materialnej egzystencji ${ }^{4}$.

Dokumenty te były przedmiotem moich badań w kontekście monograficznego opracowania klasztornego skryptorium. Ich wyniki zarysowo opublikowano w komu-

${ }^{1}$ Prof. dr hab. Andrzej Wałkówski, (ur. 1959), ukończył studia historyczne na Uniwersytecie Wrocław-
skim (1983), pracę doktorską napisaną pod kierunkiem prof. dr. hab. Wacława Korty Dokumenty i kan-
celarie ksiąząt legnickich do końca XIII wieku obronił w tamtejszym Instytucie Historycznym (1989).
Przebywał na stypendium Fundacji H. Hertza na uniwersytecie w Münster pod opieką naukową prof.
Ilpo Tapani Piirainena (1994). Stopień doktora habilitowanego (1998) uzyskał na podstawie pracy Skryp-
toria cystersów filiacji portyjskiej na Ślasku do końca XIII wieku, która otrzymała nagrodę Ministra Edukacji
Narodowej (1999), tytuł profesora uzyskał w 2011 roku. Zawodowo jest związany z Uniwersytetem
Łódzkim, z Katedrą Bibliotekoznawstwa i Informacji Naukowej. Ponadto współpracuje z Wyższą Szkołą
Edukacji Zdrowotnej i Nauk Społecznych w Łodzi oraz Szkołą Wyższą Przymierza Rodzin w Warszawie,
prowadząc wykłady i uczestnicząc w redakcji tamtejszych wydawnictw. Zajmuje się badaniami nad kul-
turą umysłową średniowiecza, szczególnie zaś piśmiennictwem sakralnym i pragmatycznym cystersów
oraz średniowiecznym biskupstwem lubuskim. Inny kierunek badawczy to prace nad wykorzystaniem
informatyki w nauce historycznej. Na tym polu współpracuje on z dr. Bogdanem Tropakiem - informa-
tykiem i matematykiem z Uniwersytetu Zielonogórskiego. Współpraca ta zaowocowała opracowaniem
i wdrożeniem kilku specjalistycznych komputerowych programów bazowych dla badań historycznych
i generalnie humanistycznych - program Diploma (dwie wersje) FAUXPAR, Codex i Codex 2 oraz Fisz-
ka. Jest autorem książki Skryptorium klasztoru cystersów w Mogile do końca XIII wieku (Łódź 2009). Pre-
zentowany referat stanowi fragment badań tegoż skryptorium.
${ }^{2}$ B. Łoziński, Leksykon zakonów w Polsce, Warszawa 1998, s. 41.
${ }^{3}$ M. Pirożyński, Zakony męskie w Polsce, Lublin 1937, s. 58; J. Stożek OCist. opat prezes, Przedmowa,
[w:] Cystersi w społeczeństwie Europy Środkowej, red. A. M. Wyrwa, J. Dobosz, Poznań 2000, s. 5.
${ }^{4}$ Zob. K. Skupieński, Funkcje matopolskich dokumentów prywatnoprawnych do roku 1306, Lublin 1990, s. 69. 
nikacie wydanym w roku $2007^{5}$. W dwa lata później wydano na temat skryptorium trzy publikacje. Dwie z nich dotyczyły dokumentów królów, książąt polskich i ich urzędników ${ }^{6}$ oraz duchownych diecezji krakowskiej ${ }^{7}$. Publikacje te dotyczyły tych dyplomów, które zredagowano lub spisano na czysto w klasztorze. Trzecia stanowi pełne, monograficzne opracowanie skryptorium opactwa cystersów Mogile ${ }^{8}$.

Przedmiotem zainteresowań niniejszego komunikatu są trzy dokumenty wystawione przez przedstawicieli małopolskiej elity średniowiecznej. Pierwszy z nich został wydany w Krakowie 21 maja 1228 przez krakowskiego sołtysa Piotra, który sprzedał klasztorowi cystersów w Mogile wieś Trusinów za 50 grzywien srebra?. Autentyczność tego dokumentu była przedmiotem osobnych badań ${ }^{10}$. Drugi dyplom wystawił Racibor syn Wojciecha 24 maja 1230 roku, sprzedając swoją wioskę Zrasową za 40 grzywien cystersom w Mogile ${ }^{11}$. Wreszcie trzeci wydano 17 IX 1231 roku w związku z tym, że Szaweł i Sąd, synowie komesa Dobiesława Prandocica Odrowąża, oraz Dobiesław, syn Wisława Prandocica Odrowąża, w raz z innymi krewnymi zrzekli się praw do Mogiły, Prandocina oraz Mikułowic, które nadali wcześniej cystersom Wisław i Iwo Odrowąż ${ }^{12}$.

Interesujące może być miejsce sporządzenia owych trzech dokumentów. Chodzi o to czy i w jakim stopniu powstały one w klasztornym skryptorium. Chciałbym ustalić proweniencję redakcji dokumentów i czy mamy do czynienia z dyktatem skryptorium cystersów. Czy są jakieś cechy stylistyczne tekstu, które mogą za tym przemawiać. Być może spotykamy je w dyplomach innych wystawców dla opactwa cystersów w Mogile. Jakich formuł dotyczą. Poprzez porównania ich stylistyki ustalimy, czy stanowiące przedmiot badań trzy dokumenty zostały zredagowane w klasztorze cystersów, w Mogile. Następny cel naszych rozważań dotyczy pisma. Musimy stwierdzić,

\footnotetext{
${ }^{5}$ A. Wałkówski, Z badań nad skryptorium mogilskim do końca XIII wieku, [w:] Ingenio et humilitate. Studia z dziejów zakonu cystersów i Kościoła na ziemiach polskich dedykowane Ojcu Opatowi dr. Eustachemu Kocikowi OCist., red. A. M. Wyrwa, Poznań-Katowice-Wąchock, 2007, s. 267-277.

${ }^{6}$ Tenże, Obecność cech kancelaryjnych mogilskiego skryptorium $w$ dokumentach królów i ksiazząt polskich oraz ich urzędników do końca XIII wieku, [w:] Kościót i Pañstwo. W dziejach, źródtach i studiach nad przeszłościa, red. M. Stawski, Warszawa 2008 [druk 2009], s. 19-46.

${ }^{7}$ Tenże, Obecność cech kancelaryjnych mogilskiego skryptorium $w$ dokumentach biskupów krakowskich i innych duchownych diecezji krakowskiej do końca XIII wieku, [w:] Scriptura. Diploma. Sigillum. Prace ofiarowane Profesorowi Kazimierzowi Bobowskiemu, red. J. Karczewska, J. Zdrenka, Zielona Góra 2009, s. 171-195.

${ }^{8}$ Tenże, Skryptorium klasztoru cystersów w Mogile do końca XIII wieku, Łódź 2009, całość.

9 Zbiór Dokumentów Klasztoru Mogilskiego przy Krakowie, wyd. E. Janota, Kraków 1865 (dalej cyt. ZDKM), nr 8. Dokument zachowany w oryginale w Archiwum Cystersów Mogilskich w Krakowie, Dyplomy pergaminowe (dalej cyt. ACM, Kr., Dypl. perg.), sygn. 7; A. Wałkówski, Skryptorium klasztoru cystersów w Mogile..., s. 193 (regest nr 4).

${ }^{10}$ A. Wałkówski, Studia nad autentycznościa dokumentu krakowskiego sołtysa Piotra dla cystersów mogilskich z 1228 roku, [w:] Ludzie i ksiażki. Studia i szkice bibliograficzno-biograficzne. Ksiegga pamiątkowa dedykowana Profesor Hannie Tadeusiewicz, red. E. Andrysiak, współpraca J. Konieczna, A. Walczak-Niewiadomska, M. Rzadkowska, Łódź 2011, s. 101-110.

${ }^{11}$ ZDKM nr 10; dokument zachowany w oryginale w ACM, Kr., Dypl. perg., sygn. 10; A. Wałkówski, Skryptorium klasztoru cystersów w Mogile..., s. 194 (regest nr 5).

${ }^{12}$ ZDKM nr 12; dokument zachowany w oryginale w ACM, Kr., Dypl. perg., sygn. 12; A. Wałkówski, Skryptorium klasztoru cystersów w Mogile..., s. 194 (regest nr 7).
} 
czy dukt badanych dokumentów zdradza cechy szkoły klasztornego skryptorium i czy występują one w innych dyplomach cystersów.

Na początek przyjrzymy się redakcji najstarszego z wymienionych wyżej dyplomów krakowskiego sołtysa Piotra z 1228 roku $^{13}$. Łatwo zauważyć, że stylistyczna budowa jego tekstu jest bardzo podobna do trzech innych dokumentów, których odbiorcą był klasztor cystersów w Mogile. Pierwszy z nich został wystawiony przez Pęcława kustosza katedry krakowskiej, drugi zaś przez wojewodę sandomierskiego Pakosława — obydwa pochodzą z 1228 roku $^{14}$. Te dwa dokumenty zostały zredagowane w klasztornym skryptorium ${ }^{15}$. W tym układzie należy przypuszczać, że i wyżej wymieniony dokument sołtysa Piotra będzie nosił dyktat klasztoru cystersów ${ }^{16}$. Przyjrzyjmy się wszystkim trzem dyplomom:

\begin{tabular}{|c|c|c|}
\hline $\mathrm{ZDK}$ & ZDKM nr 7 & ZDKM nr 8 \\
\hline sand & dry krakowskiej & Piotr sol \\
\hline $\begin{array}{c}\text { [...] presentibus et futuris, quod } \\
\text { ego Pacozlaus, [...] } \\
\text { in presentia nobilium, } \\
\text { quorum sunt ista nomina } \\
\text { [...] Acta sunt hec anno } \\
\text { gratie } M^{\circ} C C^{\circ} X X^{\circ} V_{I I}{ }^{\circ} \\
\text { nonas Maii ad ecclesiam } \\
\text { sancti Andree in curia } \\
\text { domini Radoch procurtoris } \\
\text { Cracoviensis }\end{array}$ & $\begin{array}{l}\text { Ego Panzlaus, [...] notum facio } \\
\text { omnibus, presentibus et futuris, } \\
\text { quod [...] sub horum virorum } \\
\text { testimonio, quorum sunt nomina } \\
\text { [...] Acta sunt hec anno gratie } \\
M^{\circ} \text { CC XX' }{ }^{\circ} \text { VII' } \text { in ecclesia beati } \\
\text { Wencezlai, die dominica XII } \\
\text { kalendas Iunii in presentia domini } \\
\text { Petri, primi abbatis de Clara Tumba }\end{array}$ & $\begin{array}{c}\text { Ego Petrus, }[. . .] \text { notum facio } \\
\text { omnibus, presentibus } \\
\text { et futuris [...] sub horum virorum } \\
\text { testimonio } \\
\text { [...] Acta sunt hec anno Domini } \\
M^{o} C C^{0} X X^{\circ} \text { VIII } I^{\circ} \text { die dominica in } \\
\text { ecclesia beati Wencezlai XII } \\
\text { kalendas Iunii, procurante } \\
\text { domino Petro, primo abbate } \\
\text { Clare Tumbe }\end{array}$ \\
\hline
\end{tabular}

Warto zaznaczyć, że promulgację sformułowaną identycznie z tą, która wystąpiła wdokumencie sołtysa Piotra, spotykamy w dyplomie z 1230 roku wystawionym przez wojewodę krakowskiego Marka, który nosi dyktat klasztornego skryptorium ${ }^{17}$. Podobieństwo stylistyczne: notum facimus presentibus et futuris znajdujemy w dyplomie innego wojewody krakowskiego - Włodzimierza z roku 1238, który nosi dyktat klasztornego skryptorium ${ }^{18}$. Pewne podobieństwa spotykamy w promulgacji w drugim z badanych trzech dokumentów - Racibora Wojciechowicza z 1230 roku: notum

${ }^{13} \mathrm{ZDKM}$ nr 8.

${ }^{14}$ Tamże, nr 6 i 7.

${ }^{15}$ K. Mieszkowski, Studia nad dokumentami katedry krakowskiej XIII wieku. Poczatki kancelarii biskupiej, Wrocław-Warszawa-Kraków-Gdańsk 1974, s. 50-51 (przyp. 57-61), 111-112 (regest nr 21); A. Wałkówski, $Z$ badań nad skryptorium mogilskim..., s. 272; tenże, Obecność cech kancelaryjnych mogilskiego skryptorium $w$ dokumentach królów i ksią̇ą polskich..., s. 30-31; tenże, Skryptorium klasztoru cystersów $w$ Mogile..., s. 104; tenże, Obecność cech kancelaryjnych mogilskiego skryptorium w dokumentach biskupów krakowskich..., s. 179-180.

${ }^{16}$ Zob. A. Wałkówski, Z badań nad skryptorium mogilskim..., s. 272-273; tenże, Skryptorium klasztoru cystersów w Mogile..., s. 104.

${ }_{17}$ ZDKM nr 11; A. Wałkówski, $Z$ badań nad skryptorium mogilskim..., s. 272-273; tenże, Skryptorium klasztoru cystersów w Mogile..., s. 104-107; tenże, Obecność cech kancelaryjnych mogilskiego skryptorium $w$ dokumentach królów..., s. 30-31.

${ }^{18}$ ZDKM nr 16; A. Wałkówski, $Z$ badań nad skryptorium mogilskim..., s. 272; tenże, Skryptorium klasztoru cystersów w Mogile..., s. 104-107; tenże, Obecność cech kancelaryjnych mogilskiego skryptorium $w$ dokumentach królów..., s. 30-31. 
facimus omnibus Christi fidelibus, presentibus ac futuris ${ }^{19}$. Dyplom ten posiada datację zbudowaną w sposób następujący: Acta sunt hec anno Domini $M^{\circ} C C^{\circ} X X X^{\circ}$ secunda feria die nativitatis beati Iohannis Baptiste, abbatizante domino Petro, primo abbate Clare Tumbe, in ecclesia sancti Vencezlai in Cracovia [...] bardzo podobną do takiej formuły występującej w omówionych wyżej trzech dokumentach z 1228 roku wojewody Pakosława, kustosza Pęcława i sołtysa Piotra ${ }^{20}$. Wspomniany dyplom Racibora ma charakterystyczną inwokację werbalną In nomine Sancte et Individue Trinitatis amen ${ }^{21}$ spotykaną w pięciu innych dokumentach ${ }^{22}$, które zredagowano w klasztorze ${ }^{23}$. Jest ona charakterystyczna dla dyplomów właśnie zredagowanych w opactwach ${ }^{24}$. Ponadto dokument Racibora posiada aprekację Unde et volo, ut venditio mea rata et inconcussa perpetuo maneat monachis de Clara Tumba ${ }^{25}$. Sama aprekacja była rzadką formułą, która mogła świadczyć o dyktacie odbiorcy ${ }^{26}$. Trzeci z dyplomów stanowiących przedmiot moich badań, wystawiony przez Szawła, Sąda i Dobiesława 17 IX 1231 roku został zaopatrzony w formułkę, która w literaturze bywa nazywana także formułą mówiącą o motywach religijnych działania wystawcy ${ }^{27}$. Podobną do niej stylizację spotykamy w dokumencie księcia Bolesława Wstydliwego z 1 X 1244 roku zredagowanym w skryptorium klasztoru cystersów w Mogile ${ }^{28}$. Porównajmy je:

\begin{tabular}{|c|c|}
\hline ZDKM nr 12 & ZDKM nr 21 \\
\hline Szaweł, Sąd i Dobiesław Odrowążowie & Bolesław Wstydliwy \\
\hline 17 IX 1231 & 1 X 1244 \\
\hline $\begin{array}{c}\text { Ob remedium animarum nostrarum et parentum } \\
\text { nostrorum Deo et sancte Marie promittimus et iure } \\
\text { iurando frmamus }\end{array}$ & Ob remedium anime sue et suorum parentum \\
\hline
\end{tabular}

${ }^{19} \mathrm{ZDKM}$ nr 10.

${ }^{20}$ Por. tamże, nr 10 z nr 6, 7 i 8; A. Wałkówski, Skryptorium klasztoru cystersów w Mogile..., s. 104.

${ }^{21} \mathrm{ZDKM}$ nr 10.

${ }^{22}$ Tamże, nr 14, 21, 23, 35, 61; Z. Mazur, Studia nad kancelarią księcia Leszka Czarnego, Wrocław 1975, s. $156-157$.

${ }^{23}$ A. Wałkówski, $Z$ badań nad skryptorium mogilskim..., s. 272-273; tenże, Skryptorium klasztoru cystersów w Mogile..., s. 104-107 i 109-110; tenże, Obecność cech kancelaryjnych mogilskiego skryptorium $w$ dokumentach królów..., s. 26-30.

${ }^{24}$ Zob. A. Gut, Formularz dokumentów książą zachodniopomorskich do połowy XIV wieku, Szczecin 2002, s. 70 (Czytelnik znajdzie tam dalszą literaturę i źródła).

${ }^{25} \mathrm{ZDKM}$ nr 10.

${ }^{26}$ Widać to dobitnie w dokumentach książąt zachodniopomorskich - A. Gut, dz. cyt., s. 235.

${ }^{27}$ Może warto ją włączyć do formularza jako osobną część, chociaż uważa ją się za element niesamodzielny łączony z narracją lub arengą. J. Grabowski, Ze studiów nad dokumentami i kancelarią Siemowita III księcia mazowieckiego (1342-1360), „Miscellanea Historico-Archivistica”, t. 4: 1994, s. 148; M. Bielińska, Kancelaria Władystawa Łokietka w latach 1296-1299. Ze studiów nad kancelaria wielkopolska, „Studia Źródłoznawcze”, T. 6: 1961, s. 31-32; Z. Mazur, dz. cyt., s. 34; A. Wałkówski, Dokumenty i kancelaria księcia legnickiego Henryka V Grubego, Wrocław 1991, s. 42, przyp. 48; tenże, Skryptoria cystersów filiacji portyjskiej na Śląsu do końca XIII wieku, Zielona Góra-Wrocław 1996, s. 128; A. Gut, dz. cyt., s. 154.

${ }^{28}$ ZDKM nr 12 i 21; A. Wałkówski, Z badań nad skryptorium mogilskim..., s. 272-273; tenże, Skryptorium klasztoru cystersów w Mogile..., s. 105-107; tenże, Obecnośc cech kancelaryjnych mogilskiego skryptorium $w$ dokumentach królów..., s. 26-29. 
Spośród badanych trzech dokumentów rycerskich dwa zostały zaopatrzone w listę świadków - Racibora (1230) ${ }^{29}$ oraz Szawła, Sąda i Dobiesława $(1231)^{30}$. Pierwszy z nich prezentuje następującą tendencję do hierarchicznej kolejności świadków duchownych: arcybiskupi, biskupi, dziekani, archidiakoni, prepozyci, przeorzy, scholastycy, kustosze, kanonicy spotykaną w siedmiu innych dyplomach klasztoru cystersów w Mogile wydanych przez różnych wystawców ${ }^{31}$. Drugi z nich cechuje następująca skłonność do kolejności świadków świeckich: książęta, wojewodowie, kasztelanowie, stolnicy, cześnicy widoczna w pięciu innych dyplomach klasztornych, których wystawcami były rozmaite osoby ${ }^{32}$. Obydwa schematy kolejności świadków stanowią cechę dyktatu skryptorium opactwa w Mogile ${ }^{33}$. Dokument Szawła, Sąda i Dobiesława posiada eksplicit testacji et alii quam plurimi predictorum ducum tam milites, quam ministeriales ${ }^{34}$. Podobieństwa spotykamy w pięciu dokumentach zredagowanych w Mogile, ale nie są one szczególnie mocne ${ }^{35}$. Omawiany dokument Szawła, Sąda i Dobiesława z 1231 roku posiada w datacji oznaczenie indykcji, które wystąpiło $\mathrm{w}$ sześciu innych dyplomach ${ }^{36}$ oraz epakty i konkurrenty widoczne w innym, klasztornym dokumencie ${ }^{37}$. Zostały one zredagowane w klasztorze ${ }^{38}$. Zdaniem Agnieszki Gut, epakty i konkurrenty mogą świadczyć o dyktacie cystersów ${ }^{39}$. W trzynastowiecznym dyktacie klasztoru cystersów w Mogile mamy jednak tylko dwa takie przypadki ${ }^{40}$. Natomiast brak inwokacji w dokumencie Szawła, Sąda i Dobiesława ${ }^{41}$ jest spotykany częściej w dokumentach zredagowanych w klasztorze do końca XIII stulecia, bo aż sześć razy ${ }^{42}$. W tym układzie możemy przyjąć, że omawiane trzy dyplomy wystawione przez przedstawicieli rycerstwa zredagowano w skryptorium klasztoru cystersów, w Mogile.

Przystąpmy teraz do omówienia pisma wyżej wymienionych dokumentów. Pierwszy z nich wystawiony przez sołtysa Piotra z 1228 roku został sporządzony przez tę samą rękę, co inny dyplom dla cystersów w Mogile, także pochodzący z tego roku, ale

\footnotetext{
${ }^{29}$ ZDKM nr 10.

${ }^{30}$ Tamże, nr 12.

${ }^{31}$ Por. tamże, nr 10 z nr 7, 14, 18, 21, 23, 25, 29.

${ }^{32}$ Por. tamże, nr 12 z nr 6, 11, 32, 33 i 61.

${ }^{33}$ A. Wałkówski, Skryptorium klasztoru cystersów w Mogile..., s. 105 (tam jest także literatura dotycząca kolejności świadków w dokumentach) i 120.

${ }^{34} \mathrm{ZDKM}$ nr 12.

${ }^{35}$ Tamże, nr 7, 11, 16, 18 i 22; A. Wałkówski, Skryptorium klasztoru cystersów w Mogile..., s. 105-106.

${ }^{36}$ Por. ZDKM nr 12 z 18, 32, 33, 35, 37 i 42.

${ }^{37}$ Zob. tamże, nr 12 i 37.

${ }^{38}$ A. Wałkówski, Skryptorium klasztoru cystersów w Mogile..., s. 104-110.

${ }^{39}$ A. Gut, dz. cyt., s. 227-228 (Autorka podaje jako przykład zachodniopomorską podstawę źródłową iliteraturę).

${ }^{40}$ A. Wałkówski, Skryptorium klasztoru cystersów w Mogile..., s. 99.

${ }^{41}$ ZDKM nr 12.

${ }^{42}$ Tamże, nr 11, 16, 25, 27, 29, 44; zob. A. Wałkówski, Skryptorium klasztoru cystersów w Mogile..., s. $104-110$.
} 
wystawiony przez kustosza katedry krakowskiej Pęcława ${ }^{43}$. Pismo obu dokumentów pochodzi z klasztornego skryptorium i ma charakter wczesnogotycki. Do cech gotyckich zaliczymy przewagę okrągłego $d$ oraz symboliczny skrót na et występujący tylko w postaci zbliżonej do arabskiej siódemki. Zarazem widzimy również cechy pisma romańskiego: brak zasady Wilhelma Meyera, rzadko występujące proste $d$, oraz obecne e-caudata. Pismo posiada budowę liter typową dla pierwszej połowy XIII stulecia, na co wskazuje wygląd dużych liter $(A, I, M, R, T, V)$, małych $(b, c$, proste $d, e, h, l, r)$ jak również charakter zbitki literowej $c t^{44}$.

Pismo dokumentu Racibora syna Wojciecha z 1230 roku ma charakter romańsko-gotycki, a świadczy o tym przewaga prostego $d$ nad okrągłym, stosowanie symbolicznego skrótu na et na ogół w postaci \&, brak zasady Wilhelma Meyera, a ponadto nie ma $e$-caudata ${ }^{45}$. Pismo tej ręki pochodzi z pierwszej połowy XIII wieku, co widać po wyglądzie dużych liter: $A, H$, $I$, uncjalnego $M, V$ oraz małych: $b$, prostego $d, h, l, p$, okraggego $s, t$, oraz ligatury $c t^{46}$.

Dokument Szawła, Sąda i Dobiesława Odrowązów z 1231 roku sporządzono pismem wczesnogotyckim. Za cechy typowo gotyckie możemy uznać brak prostego $d$ oraz e-caudata. Jednak obok ewidentnie typowo gotyckiej cechy, jaką jest symboliczny skrót na $e t$ w postaci zbliżonej do arabskiej siódemki spotykamy także jego romańską formę: \&. Nie ma zupełnie zasady Wilhelma Meyera. Pismo prezentuje szkołę skryptorium klasztoru cystersów w Mogile. Pochodzi z pierwszej połowy XIII wieku o czym świadczy wygląd dużych liter: $B, D, U$; małych: $a, b, c, e, f$ jak również zbitek literowych: $c t$ oraz $s t^{47}$.

Rekapitulując nasze rozważania, omawiane trzy dokumenty dla klasztoru cystersów w Mogile z 1228, 1230 i 1231 roku, wystawione przez krakowskiego sołtysa Piotra, Racibora Wojciechowicza oraz dziedziców Prandocina Szawła, Sąda i Dobiesława Odrowążów, zostały zredagowane i spisane na czysto w klasztornym skryptorium.

\footnotetext{
${ }^{43}$ Zob. ACM, Kr., Dypl. perg., sygn. 6 i 7; A. Wałkówski, Skryptorium klasztoru cystersów w Mogile..., s. 129-132; tenże, Obecność cech kancelaryjnych mogilskiego skryptorium w dokumentach biskupów krakowskich..., s. 183-184; tenże, Studia nad autentycznościa dokumentu krakowskiego soltysa Piotra..., s. 103-108, gdzie Czytelnik znajdzie dowód tożsamości pisarza obu dokumentów na podstawie szczegółowej, porównawczej analizy paleograficznej; K. Mieszkowski, dz. cyt., s. 17 i 96.

${ }_{44}$ Por. ACM, Kr., Dyplomy pergaminowe, sygn. 6 i 7 (fot. 1 i 2) z Wł. Semkowicz, Paleografia tacińska, Kraków 2002, s. 322; A. Gieysztor, Zarys dziejów pisma tacińskiego, Warszawa 2009, s. 125-126 (dla niespecjalistów wyjaśniam, że zasada W. Meyera polega na zrastaniu się wspólną ścianką dwóch sąsiednich, wzajemnie do siebie wypukłych liter - np. $b+o=b o$ ); W. Heinemeyer, Studien zur Gotischen Urkundenschrift, Köln-Graz 1962, tab. 1/2 , 3/4 , 5/6 i 8/9; A. Wałkówski, Obecnośc cech kancelaryjnych mogilskiego skryptorium $w$ dokumentach biskupów krakowskich..., s. 183-184; tenże, Skryptorium klasztoru cystersów w Mogile..., s. 129-132.

${ }^{45}$ Fot. 3 (ACM, Kr., Dypl. perg., sygn. 10); zob. A. Gieysztor, $d z$. cyt., s. 125-126 i Wł. Semkowicz, $d z$. cyt., s. 322; A. Wałkówski, Skryptorium klasztoru cystersów w Mogile..., s. 132-134.

${ }^{46}$ Por. fot. 3 (ACM, Kr., Dypl. perg., sygn. 10) z W. Heinemeyer, $d z$. cyt., tab. 1/2, 3/4, 5/6 i 8/9.

${ }^{47}$ Por. ACM, Kr., Dypl. perg., sygn. 12 (fot. 4) z A. Gieysztor, dz. cyt., s. 125-126 i Wł. Semkowicz, dz. cyt., s. 322; W. Heinemeyer, dz. cyt., tab. 1/2 , 3/4 , 5/6 i 8/9; A. Wałkówski, Skryptorium klasztoru cystersów w Mogile..., s. 134-136.
} 


\section{The Origin of Office Documents of Soltis, Peter, Racibor Wojcechowicz and Three Representatives of Ancestry Odrowąż for the Cistercian Monastery in Mogiła from the Years 1228-1231}

\section{Summary}

The objects of interest are three documents of the Monastery of Cistercian in Mogiła exposed by representatives of Lesser Poland medieval elite. The first of them was edited by Cracow soltis (village administrator; commune leader), Peter, selling to Cistercians Monastery in Mogiła the village Trusinów for 50 forfeits of silver in Cracow on May 21 $1^{\text {st }}, 1228$. The second was exposed by Racibor Wojciechowicz in connection with sale (by reason of) to Cistercians in his village Zrasowa for 40 forfeits, on May $24^{\text {th }}, 1230$. The third was edited by Szawel, the Court, the sons of Dobiesław Prandocic Odrowąz, and Dobiesław, the son of Wisław Prandocic Odrowąż which together with other relatives waived their rights to Mogiła, Prandocin, and Mikułowice, previously given to the monastery by Wislaw and Iwo Odrowąż. This document was exposed on September $17^{\text {th }} 1231$.

We are interested in the place of preparation of these three documents. It's about the question of whether and to what extent they were created in the monastery scriptorium. Also to determine the editorial provenance the editorial office of documents and clarify whether we are dealing with the dictates of the Cistercian scriptorium? What are the stylistic features of the text that can speak for this? Do you find them in the diplomas of other exhibitors for the Cistercian Abbey at the Mogiła, and to which formulas they refer to? Comparing their style we will establish whether the three documents of Mogiła, which are the subject of research papers, can be edited in a Cistercian monastery scriptorium, at the Mogiła. Further considerations concern the writing. You have to answer the question if the vista of searched documents present the school of monastic scriptorium and if it is evident in other diplomas of the monastery? The analysis of design and writing of these three documents revealed that they were edited and written on purely in the monastery scriptorium. 
Fot. 1. Dokument sołtysa krakowskiego Piotra

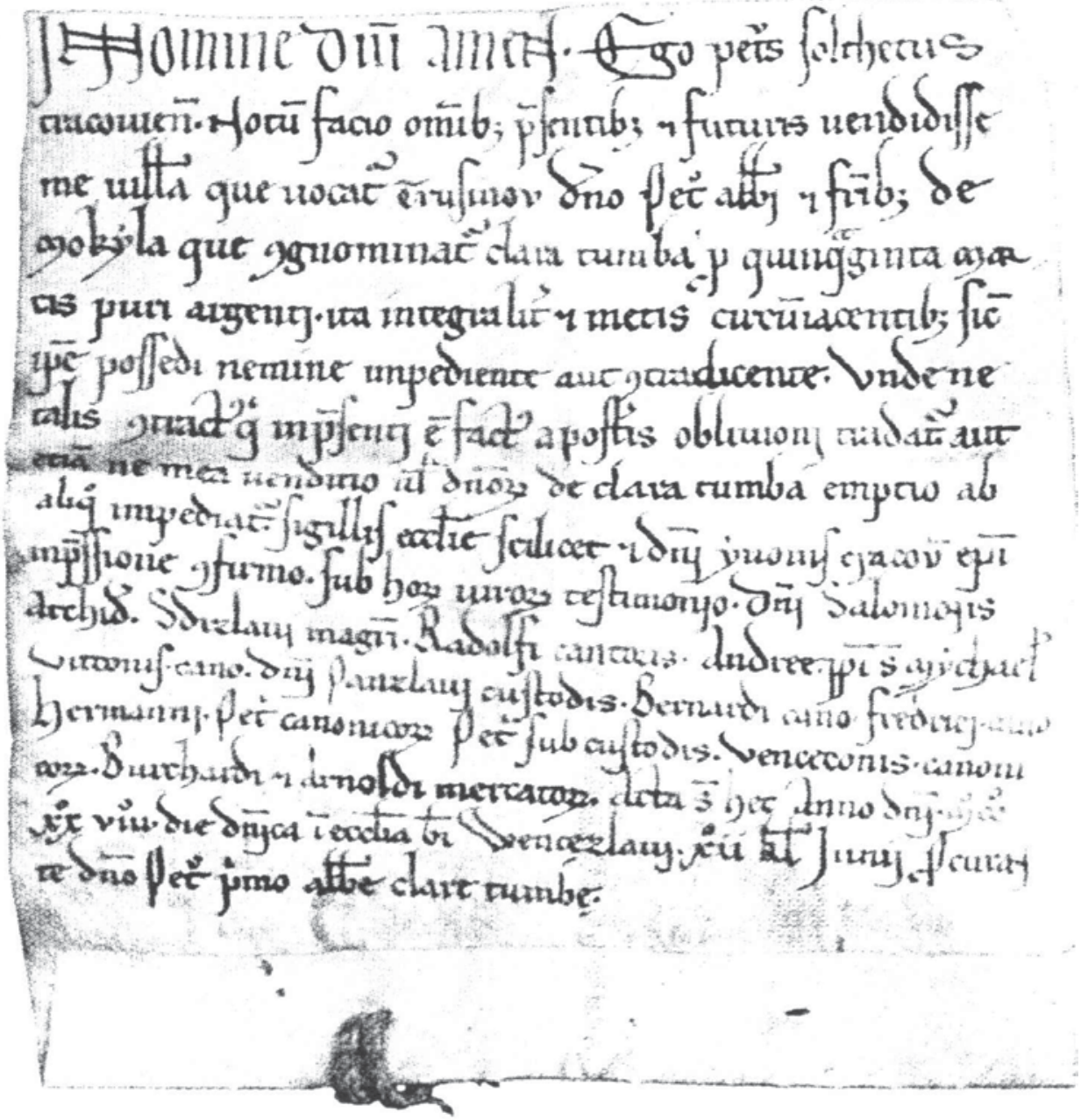

Archiwum Cystersów Mogilskich w Krakowie.

Dyplomy pergaminowe, sygnatura 7. 


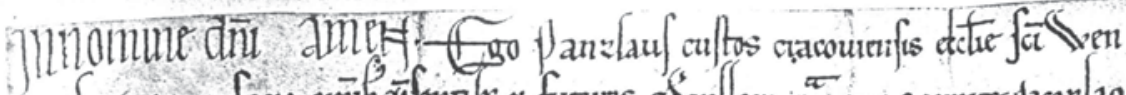

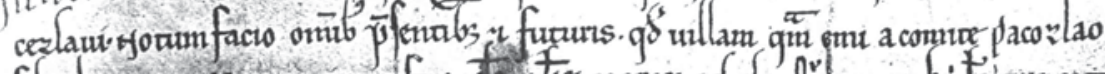

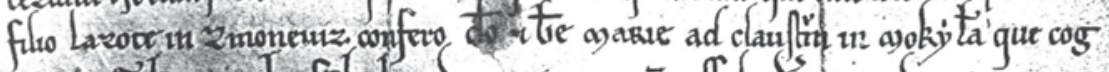

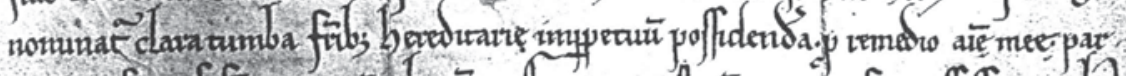

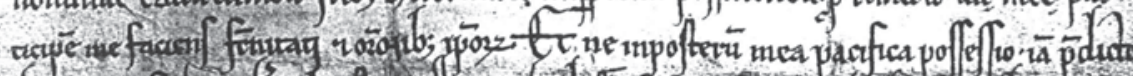
130 (S)

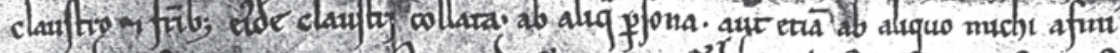

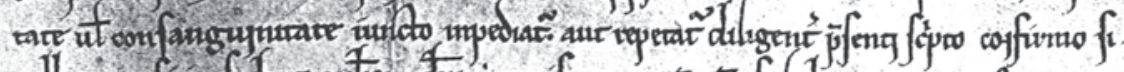

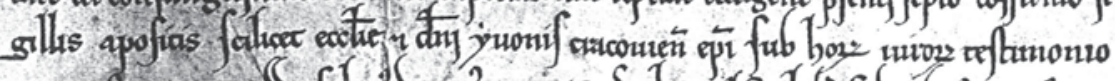

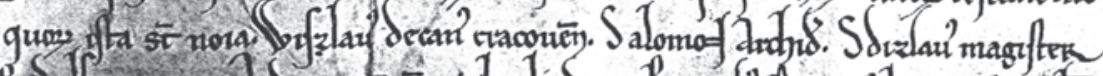

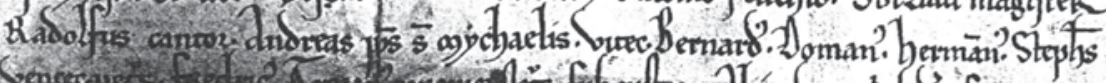

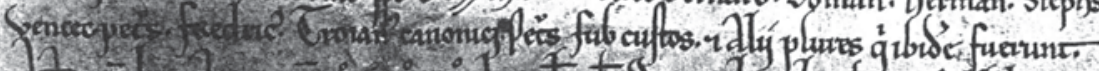

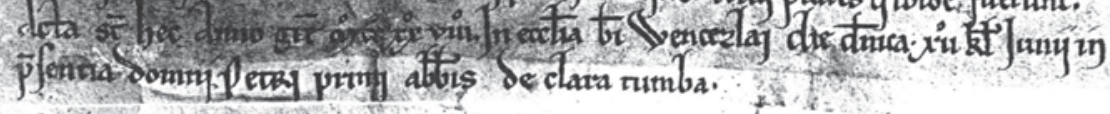
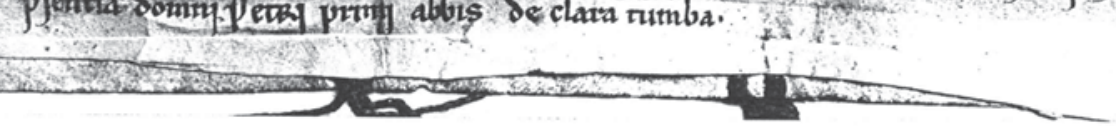

Archiwum Cystersów Mogilskich w Krakowie. Dyplomy pergaminowe, sygnatura 6.

Fot. 3. Dokument Racibora syna Wojciecha

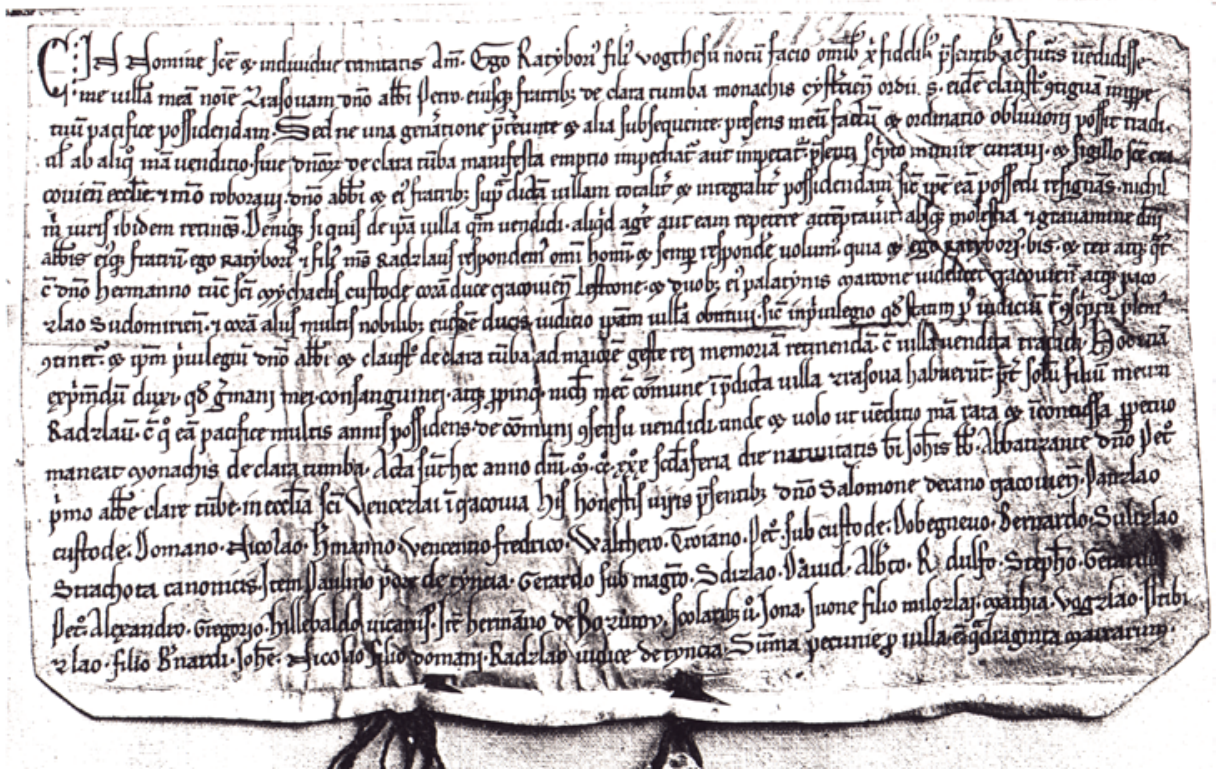

Archiwum Cystersów Mogilskich w Krakowie. Dyplomy pergaminowe, sygnatura 10. 
Fot. 4. Dokument Szawła i Sąda oraz Dobiesława Odrowążów

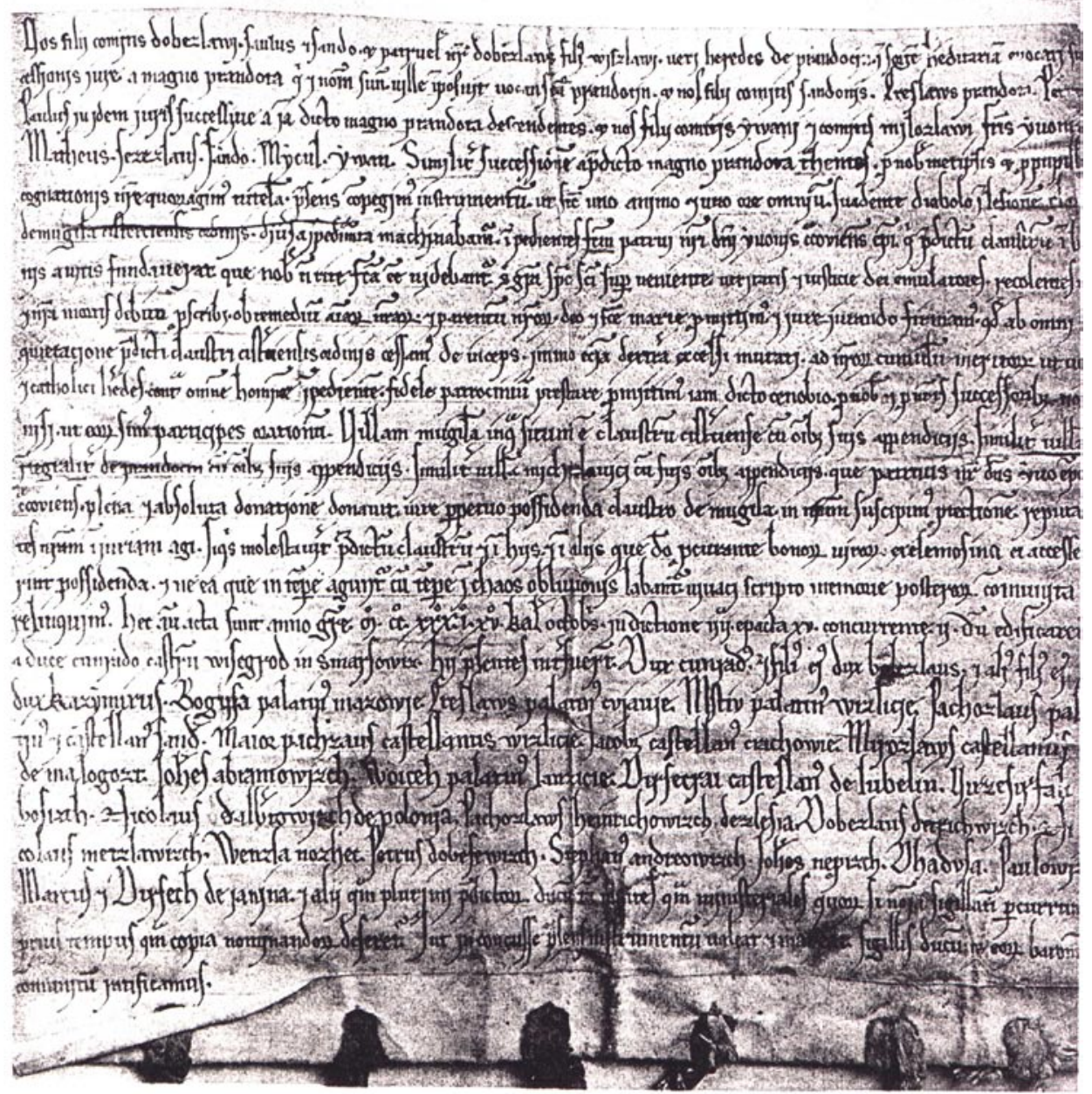

Archiwum Cystersów Mogilskich w Krakowie.

Dyplomy pergaminowe, sygnatura 12 . 